\title{
The Design of Unique Lexicon Formation of Javanese Speech in Semarang Lower Class Society
}

\author{
M. Suryadi ${ }^{1, *}$ and Sri Puji Astuti ${ }^{2}$ \\ ${ }^{1}$ Department of Indonesian literature, Faculty of Humanities, Diponegoro University, Semarang - Indonesia \\ ${ }^{2}$ Department of Indonesian literature, Faculty of Humanities, Diponegoro University, Semarang - Indonesia
}

\begin{abstract}
The research was aimed to design the formation of Javanese speech unique lexicon in Semarang lower class society. The design involved the phoneme sequence pattern and phoneme mapping in the lexicon structure. The location of the research was in the dissemination area of Semarang language in Semarang. The selection of informant used purposive sampling system. The design of the research was survey and case study. The data collection was done by structured interview, in-depth interview, and focus group discussion (FGD). The data was analyzed using agih method by changing technique of phoneme sequence, re-order of phoneme form, and harmonization of phoneme devices. The finding of this research is a design which take a form as a method that can be used to design the new forming of lexicon that categorized as the unique lexicon, all at once as the model of lexicon enrichment.
\end{abstract}

Keywords: Javanese; lexicon; lower class; speech; unique.

\section{Introduction}

The concept of life of Javanese people in society can not be detached from the order of adhi luhung which keep the communal harmony. The necessary main role is Javanese behavior as the member of society is limited by the norms and social regulations. Each of what we will done must be adaptable with the norms and social regulations, so it will forming the ideal values

The ideal value consists of five behavior orders, there are: personal order, well mannered order, respectful order, suitable order, and harmony order. The ideal values which implicates the five pillars of orders become the ideal orientation for the whole Javanese to do the social interaction, either in higher class society or lower class society. The uniqueness in interaction is more vissible in the lower class society, especially to incarnate the true self in communal surroundings

The lower class, including wong cilik[1], is the majority inhabitant of urban area included in Semarang[2]. This behavior is reflected in linguistic corridor, which are the power of speech that shows the tendency of rule penetrate: phoneme order, phoneme relation, phoneme migration, and phonotactic. This phenomenon was happened in the ring of dissemination area of Semarang language.
The focus of this research is in the internal analysis of the pattern of phoneme sequence/order, phoneme relation, phoneme migration, phonotactic harmonization in the unique lexical structure which is developed and dispersed in the ring of Semarang language usage. The findings of the research can be used as the device to identify the determining of unique lexical.

One of the parameter of unique lexical utilization in the Javanese life is the usage of emotive-dialectical lexicon in speech[3] and the naming of symbol in the building of Javanese architecture. The usage of emotivecultural lexicon is, oftentimes, influenced the life expressions, Javanese cultural norms, and the pursuance of nature power. The basic component of Javanese society life is to keep the social harmonization by prioritized the principal of concord, principal of honor, and principal of harmonization. The power of theses three pillars can be representated by the power of speech which is kept in the unique lexicons[4].

\section{Research Method}

The location of this research is in the northern coastal area of Central Java, which is focused in Semarang, especially in the ring of Semarang language usage: (1) Alun-alun Semarang, (2) Johar Market, (3) the area between Banjirkanal Barat and Banjirkanal Timur river, (4) Pusponjolo, (5) Krobokan, (6) Karangayu, (7) Kalibanteng, (8) Mrican, (9) Kapling, dan (10) Jatingaleh. 
The gathering of primary data was done by trianggulation with some methods, there were: observation, structured interview, in-depth interview, and focus group discussion.

The data was analyzed using agih method with four analysis devices, (1) Mapping technique, the technique used to explain the phoneme order in the lexicon internal structure which was signed as unique lexical. (2) Substitution technique used to trace the phoneme relation which was connected with the power of meaning of unique lexical. (3) Permutation technique used to detect the movement or migration of phoneme over the formation of new words. (4) Harmonization phonem technique used as the inherence of sound towards the lexicon forming from the result of migration phoneme.

\section{Emotive Lexicon Dialectical Dimensions}

Emotive lexicon is a word that has affective power for the speaker and hearer. This affective power has the nodes of sense and emotive power which moved the psycological act of participants of speech. That emotive power has a difference of the degree for each lexicons. The parameter of emotive power is reside in the communal psychologycal of participants. It can be happened that the same lexicon has the different emotive power. This difference is determine by the outside lingual factor. The outside lingual factors include (1) participant, (2) situation, (3) and the purpose/goal of speech.

Emotive lexicon dialectical dimensions is view of lexicons that has the growth affective degree and it is used in the usage area of Semarang language. This affective degree communally is measured by the emotive degree of Javanese speaker in Semarang.

Emotive lexicon dialectical dimension or emotivedialectical mostly found in the ngoko level of speech. Ngoko level of speech has more emotive-dialectical lexicon because this level of speech has feature which is stickly with the emotive-dialectical lexicon, there are, (1) basic level of speech that tend to have the simple form and easily to understand; (2) the most intimate, comfortable, and relaxive speech level; (3) the dialectical speech level as the place to grow the ngoko lexicon.

The emotive-dialectical lexicon which is found in Semarang langauage can be classified into three categories, there are emotive lexicon phatic category, geographical local, and metonymy. Emotive lexicon phatic category is the vocabulary that used often to start the speech, defending what it is speaking about, strenghtened the speech, and or formed as statement word. Phatic category of lexicon coherent with the cognitive value: affective and emotive.

Geographical local lexicon is the kinds of vocabulary that has the limited usage area, that is used and developed in the area where the language is
used.The lexicon types of metonymy is the mentioning of a name based on the association. The tendency of metonymy is sometimes found in the various language speech.

\section{Unique Lexicon}

Unique lexicon is the types of lexicon that has the dissemination limited area. The dissemination area is on the ring of Semarang language usage. This unique lexicon only recognizable by the community of Semarang language, outside the community no one knows aout the lexicon. This community is also limited in total. The unique lexicon is often said as the prokem language which is taken from Chinese, Arabian, Koja, and Dutch. This vocabulary in the era of 1970s used or talked from the community of gali (hoodlums). It traced that this vocabulary was created by changing the character of Javanese. There are view forms of unique lexicon which is succeed to be found in Semarang language, such as, calam 'father', coso 'husband/wife', dheyom 'woman', jayus 'one hundred',jelade 'twenty five' jelepuh 'ten'.

\section{Unique Lexicon Design}

Unique lexicon that becomes the specific of Semarang language partly can be traced the process of formation. The formula of unique lexicon formation based on the changing the order of Javanese characters[5].

The process of unique lexicon formation can be done by utilized the phoneme order. This process can be said to complete the process of unique lexicon formation before. The offering concept in this research is utilized the order of phoneme in Javanese character in the form of disk. That disk model can be abstraction in figure 1

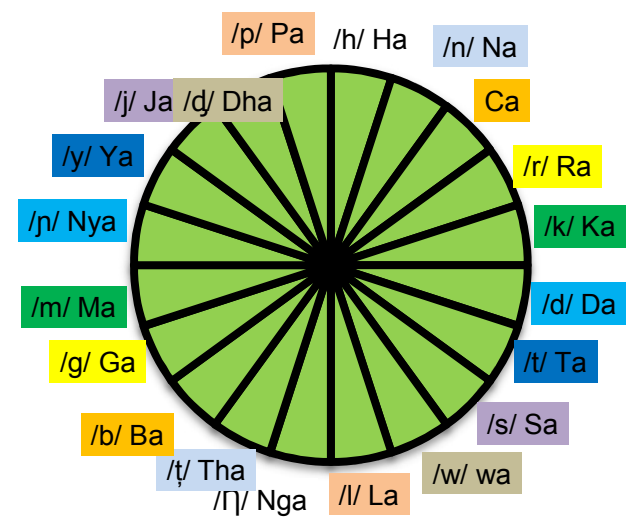

Figure 1: Disc Method: The sequence of phonemes and Javanese script 


\section{Conclusion}

The finding of this research is the Javanese of coastal in Semarang has unique characteristic, that is the richment of lexicon which is formed (1) emotivecultural lexicon: phatic category, geographical local/dialectal, metonymy; (2) unique lexicon: the formation of this lexicon can be done by disc method. The method of disc can be used all at once to design the new forming lexicon that can be categorized as the unique one. The emotive-cultural lexicon in the coastal Javanese community in the city of Semarang can be used as a symbol of a society that loves the green environment and avoids the use of carbon .

\section{References}

1. Koentjaraningrat. "Pengantar Ilmu Antropologi". (2009).

2. H. Purwoko. Jawa Ngoko: Ekspresi Komunikasi Arus Bawah. (2008).

3. Mulder, N. Pribadi dan Masyarakat di Jawa. (1985)

4. Suseno, F. M. Etika Jawa: Sebuah Analisa Falsafi tentang Kebijaksanaan Hidup Jawa. (1984)

5. Hartono. Bahasa Semarangan, Bahasa Tutur Miskin Literatur. (2010). 